\title{
Sowing environments effect on rust ( $P$. arachidis) disease in groundnut (Arachis hypogea L.)
}

\author{
S.G KANADE, A.A. SHAIKH AND J.D. JADHAV*
}

Zonal Agricultural Research Station, SOLAPUR (M.S.) INDIA

\section{ARITCLE INFO}

Received : 29.01 .2015

Revised : 08.03.2015

Accepted : 22.03.2015

\section{KEY WORDS :}

Rust of groundnut, Biometerological effect, Climatic factors
*Corresponding author:

Email: slp.aicrpam@gmail.com

\begin{abstract}
An experiment was laid out in Randomized Block Design with five sowing dates viz., $\mathrm{S}_{1}-22^{\text {nd }}$ June, $S_{2}-29^{\text {th }}$ June, $S_{3}-6^{\text {th }}$ July, $S_{4}-13^{\text {th }}$ July and $S_{5}-20^{\text {th }}$ July and four replications. The observations on initiation of rust diseases and per cent disease intensity were recorded periodically at an interval of one week after the occurrence of these diseases. In rust disease maximum temperature (0.59), morning relative humidity $(0.33)$, evaporation $(0.33)$ and bright sunshine hours (0.55) showed positive correlation with disease intensity. Whereas, minimum temperature (-0.44), evening relative humidity $(-0.58)$ and wind speed (-0.63), showed negatively significant correlation with disease intensity in Kharif season. Other climatic factors i.e. rainfall showed no significant correlation with disease intensity. The morning relative humidity and bright sunshine hours were correlated for rust disease incidence. The result from all the relevant observations indicated that the morning relative humidity (2.87) and bright sunshine hours (5.65) during the crop growing period was found to be highly significant weather conditions for rust disease development among the all other weather parameters. The multiple regression equation developed from the data in this regard is as :

$\mathrm{Y}=\mathbf{- 2 5 7 . 5 9 1}+\mathbf{2 . 8 7 9 R H}-\mathrm{I}(\mathrm{W}-1)+\mathbf{5 . 6 5 1 B S S}(\mathrm{W}-1)$
\end{abstract}

How to view point the article : Kanade, S.G., Shaikh, A.A. and Jadhav, J.D. (2015). Sowing environments effect on rust (P. arachidis) disease in groundnut (Arachis hypogea L.). Internat. $J$. Plant Protec., 8(1) : 174-180. 